\title{
MANAJEMEN SUMBER DAYA MANUSIA DI DINAS TENAGA KERJA DAN TRANSMIGRASI KABUPATEN BIMA: DAPATKAH MENINGKATKAN SEMANGAT KERJA PEGAWAI?
}

\author{
Muhammad Yusuf ${ }^{1}$, Kartin Aprianti ${ }^{2}$ \\ ${ }^{1,2}$ Sekolah Tinggi Ilmu Ekonomi Bima \\ Jln. Wolter Monginsidi Tolobali Kota Bima \\ E-mail : yusufzm.stiebima@gmail.com \\ diterima: 27/1/2020; direvisi: 20/3/2020; diterbitkan: 26/3/2020
}

\begin{abstract}
This study aims to analyze the effect of transformational leadership and organizational commitment partially and simultaneously on the morale of the employees of the Bima Regency Manpower and Transmigration Office. The sampling technique used was purposive sampling. Data analysis techniques used multiple linear regression with a sample of 49 civil servant respondents at the Bima Regency Manpower and Transmigration Office. The results showed that transformational leadership and organizational commitment influence work morale by $61.2 \%$.
\end{abstract}

Keywords: Transformational leadership, organizational commitment, employee morale

\section{PENDAHULUAN}

Menejemen Sumber Daya Manusia (SDM) dalam melakukan pendekatan pada setiap tenaga kerja/karyawan/pegawainya mengalami perubahan seiiring perubahaan tatanan struktur perekonomian sesuai Revolusi Industri 4.0. Manajemen SDM dituntut untuk melakukan pembenahan dalam berbagai sektor yang di antaranya dalam proses rekrutmen pegawai, manajemen kinerja pegawai bahkan hingga Kepemimpinan dan Komitmen Organisasi.

Kegiatan-kegiatan dalam organisasi bergantung kepada semangat kerja pegawai. permasalahan pegawai yaitu organisasi perlu memberikan perhatian lebih bagi semangat kerja bawahannya. Semangat kerja pada diri pegawai akan mempengaruhi pekerjaan yang berakibat pada maksimal atau tidaknya pekerjaan tersebut.

Dalam penelitian ini yang menjadi faktor penting menurut peneliti dalam mempengaruhi semangat kerja adalah Kepemimpinan Transformasional dan Komitmen organisasi. Kedua faktor tersebut dianggap penting karena untuk menumbuhkan semangat kerja sebagai faktor internal dalam diri pegawai memiliki pengaruh dominan dalam meningkatkan semangat kerja pegawai.

Yulk (2010) menjelaskan bahwa kepemimpinan transformasional dalam pekerjaan di sebuah organisasi adalah untuk memunculkan kapabilitas terbaik dengan cara mempengaruhi orang lain. Pegawai melakukan pekerjaan dengan bergairah dan semangat kerja tinggi akan berkembang menjadi pemimpin di bidang masingmasing dalam organisasi. Pemimpin ini dianggap mampu menjadi model pemimpin untuk menciptakan dan mengerakkan pemimpin-pemimpin yang lain.

Kepemimpinan transformasional merupakan pola kepemimpinan yang memunculkan kapabilitas yang ada pada pegawai sehingga karyawan termotivasi untuk bekerja secara optimal sehingga melakukan pekerjaan melebihi ekspektasi organisasi.

Selain membutuhkan kepemimpinan transformasional, dalam organisasi juga membutuhkan komitmen. Komitmen dalam organisasi yaitu perilaku seseorang kepada organisasinya seperti pencapaian visi dan 


\section{Jurnal Ilmiah Ekonomi dan Bisnis}

Vol. 17. No.1, Maret 2020 : 79-84

EISSN : $2442-9813$

ISSN : $1829-9822$

misi serta tujuan organisasi dengan loyalitas pegawai. Semua itu dapat dikenali dengan kepercayaan dan kemauan kuat pada nilai organisasi. Semangat kerja yang tinggi atau rendah pada pegawai bisa dikenali dari perilakunya dalam mencapai tujuan organisasi. Organisasi harus mampu menyesuaikan semangat kerja yang efektif bagi setiap pegawainya. Karena efektif bagi yang lain belum tentu yang lainnya merasa efektif. Hal ini dikarenakan kebutuhan tiap tiap pegawai, individu yang satu denga yang lainnya berbedabeda. Oleh sebab itu organisasi harus mampu menyesuaikan kebutuhan pegawai untuk meningkatkan semangat kerja yang baik.

Penelitian ini berjudul "Manajemen Sumber Daya Manusia Di Dinas Tenaga Kerja Dan Transmigrasi Kabupaten Bima:Dapatkah Meningkatkan Semangat Kerja Pegawai?" sesuai dengan latar belakang yang telah uraikan diatas.

Menganalisis

pengaruh kepemimpinan transformasional dan komitmen organisasi terhadap semangat kerja pegawai baik secara parsial maupun simultan pada Dinas Tenaga Kerja dan Transmigrasi Kabupaten Bima merupakan tujuan dari penelitian ini.

\section{TINJAUAN PUSTAKA}

Mengukur tinggi-rendahnya semangat kerja maka perlu mempelajari aspek-aspek yang mempengaruhi semagat kerja. Menurut Hasibuan (2013), dalam bekerja, seseorang memiliki alasan sendiri untuk menungkatkan semangat kerjanya. Hal ini berakibat pada pegawai memiliki kualitas bertahan dalam kesulitas dan memiliki semangat dalam kelompok kerja.

Mangkunegara (2008) juga menjelaskan bahwa semangat kerja menjadi hal yang tidak bisa diukur serta dikendalikan dan dapat terlihat melalui pengaruh kuat atas hubungan manusiawi dalam organisasi. Semangat mengacu pada sikap baik pegawai terhadap pekerjaan dan organisasinya.

Sejalan dengan yang disampaikan oleh mangkunegara, Fane dkk (2016) dalam penelitiannya menjelaskan semangat atau moriil kerja adalah kemampuan dan kemauan seseorang dalam berusaha mengejar aau mencapai tujuan bersama dalam organisasi. Dengan demikian maka dalam penelitian ini semangat kerja adalah kegiatan serta perasaan yang dimiliki dalam setiap usaha untuk mencaai tujuan organisasi.

Menurut galih dan Azis (2017) dalam penelitiannya menyebutkan kepemimpinan adalah tindakan mempengaruhi dalam organisasi secara bersama-sama dengan cara memotivasi bawahannya untuk mencapai tujuan. Kepemimpinan transformsional menjadi penting karena mampu menumbuhkan potensi berkembang pada pegawainya.

Danim (2004) juga menyebutkan inovasi dalam organiasi terbantu oleh adanya kepemimpinan transformaional yang diterapkan organisasi. Hal ini dapat memberikan kemajuan visi dan mendorong pengikut atau bawahannya. Karisma, inspirasi, pertimbangan individual dan stimulasi intelektual merupakan empat skala kepemimpinan dalam organisasi.

Dengan demikian Kepemimpinan transformasional dalam penelitian ini adalah pengaruh pemimpin terhadap bawahan. Kepercayaan, kebanggaan, loyalitas dan rasa hormat yang dirasakan oleh para bawahan kepada atasan serta termotivasi untuk bertindak melebihi ekspektasi organisasi. Pegawai atau pekerja adalah manusia yang mampu belajar dan mengarahkan yang terbaik bagi organisasinya yang menerapkan gaya kepemimpinan transformasional.

Supayadi (2015) menyebutkan komitmen organiasi yaitu keinginan kuat menjadi bagian organisasi serta memiliki keinginan untuk selalu berusaha dan keyakinan kuat dalam melaksanakan visi dan misi organisasi. 
Mardani (2013) dalam penelitiannya menjelaskan bahwa komitmen organisasi berpengaruh paling kuat dimana orang akan termotivasi untuk melaksanakan kegiatan oganisasi bahkan saat tidak adanya motivasi itu, dikarenakan rasa cinta dan tanggung jawab yang besar pada organisasi dan pekerjaan.

Para pegawa yang menunjukkan komitmen tinggi bagi organisasinya mempunyai kemungkinan jauh lebih besar bagi ornganisasinya. Dengan demikian pegawai yang yakin dan termotivasi kuat untuk bekerja, selalu melibatkan diri dalam pekerjaan dengan menunjukkan kinerja yang terbaik bagi organisasinya.

\section{METODE PENELITIAN}

Explanatory research dengan menggunakan pendekatan survey sampel merupakan jenis penelitian yang digunakan. Menurut Sugiyono (2010) explanatory research digunakan untuk menganalisis hubungan antaara variabel melalui pengujian hipotesis.

Kabupaten Bima dan bekerja sama dengan dinas tenaga kerja dan transmigrasi dimana lokasi penelitian dengan objek penelitian seluruh Pengawai Negeri Sipil yang bertugas di Kabupaten Bima dan bekerja sama dengan dinas tenaga kerja dan transmigrasi. Skor yang mengacu pada pemakaian skala likert adalah pengukuran variabel yang diterapkan pada peneltian ini. Analisis data diolah menggunakan bantuan SPSS sehingga diperoleh ketepatan pada alat analisanya. purposive sampling dengan mengambil sampel dari anggota populasi yang disesuaikan dengan keinginan dan kepentingan yang diaggap oleh peneliti sesuai dengan kebutuhan penelitian sebagai teknik pengambilan sampel oleh penulis. dalam hal ini peneliti menggunakan sampel yaitu seluruh pegawai negeri Sipil (PNS) yang ada di lokasi penelitian sejumlah 49 responden.

Analisis linear berganda (Multiple Regression Analysis) sebagai teknik analisa data dan statistik untuk menguji baik secara parsial maupun simultan variabel kepemimpinan transformasional (X1), komitmen organisasi (X2) dan semangat kerja (Y). Guna menjaga keakuratan analisis data, peneliti akan menggunakan software Statistical Packagefor Social Science (SPSS) versi 19 for windows.

\section{HASIL DAN PEMBAHASAN}

Pengujian instrumen keabsahan data (validity) menggunakan uji daya diskirimasi item yaitu korelasi pearson product moment (PPM). Kriteria pengukurannya adalah $r_{\text {hitung }}>r_{\text {tabel }}$ maka item pertanyaan adalah valid (sugiyono, 2010). Berdasarkan hasil analisis menunjukkan bahwa dari 24 item pernyataan yang diajukan dinyatakan valid. Selanjutnya, uji instrumen reliabilitas variabel menggunakan analisis cronbach's alpha, dinilai reliabel jika $\alpha>0,60$ (suharsimi, 2010). Setelah melakukan uji instrumen maka Instrumen dalam penelitian ini memiliki tingkat reliabilitas tinggi (reliabel).

Uji Asumsi Klasik

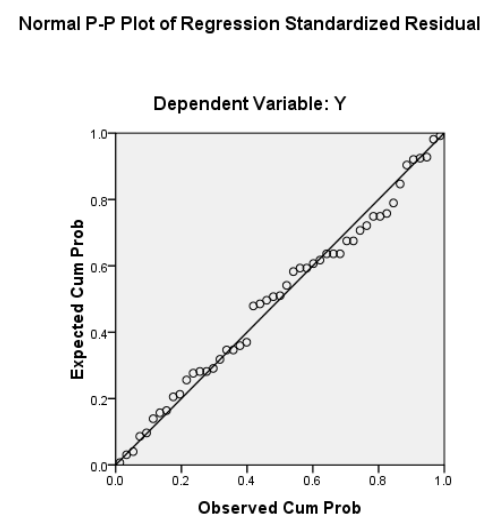

Sumber: Data diolah, 2020

Dari output plot data diatas dapat diperhatikan bahwa data penelitian telah memenuhi syarat normalitas sehingga variabel bebas (ndependent) dalam penelitian ini memenuhi normalitas. 


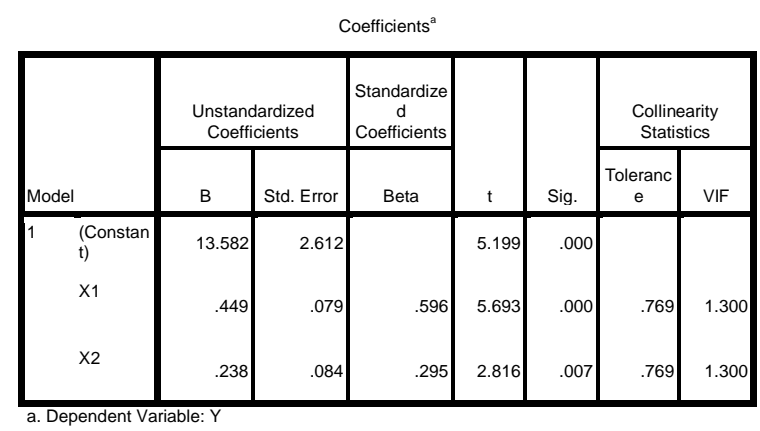

Sumber: Data diolah, 020

Variabel penelitian tidak terjadi gejala multikolinearitas dapat dilihat dari nilai tolerance $\leq 0,10$ dan nilai VIF $\leq 10$ pada setiap instrumen dari masing-masing variabel.

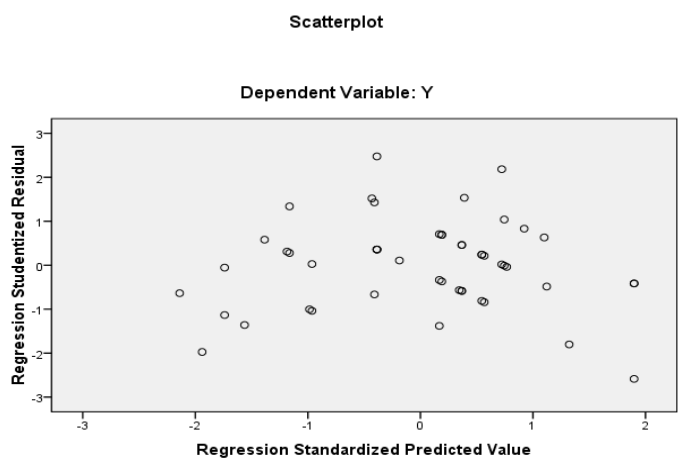

Sumber: Data diolah, 2020

Data menyebar diatas dan dibawah angka 0 pada sumbu Y. Uji heteroskedastisitas diperoleh hasil analisis pada output Scatterplot yang menunjukkan bahwa tidak terdapat pola tertentu dan sehingga variabel dalam penelitian ini terbebas dari heteroskedastisitas.

Uji Regresi Linear Sederhana

Coefficients $^{a}$

\begin{tabular}{|c|c|c|c|c|c|c|}
\hline \multirow{2}{*}{\multicolumn{2}{|c|}{ Model }} & \multicolumn{2}{|c|}{$\begin{array}{l}\text { Unstandardized } \\
\text { Coefficients }\end{array}$} & \multirow{2}{*}{\begin{tabular}{|c|}
$\begin{array}{c}\text { Standardized } \\
\text { Coefficients }\end{array}$ \\
Beta \\
\end{tabular}} & \multirow[b]{2}{*}{$t$} & \multirow[b]{2}{*}{ Sig. } \\
\hline & & B & Std. Error & & & \\
\hline 1 & $\begin{array}{l}\text { (Constan } \\
\text { t) }\end{array}$ & 13.582 & 2.612 & & 5.199 & .000 \\
\hline & x1 & .449 & .079 & .596 & 5.693 & .000 \\
\hline & X2 & .238 & .084 & .295 & 2.816 & .007 \\
\hline
\end{tabular}

Dependent Variable: $Y$

Sumber: Data diolah, 2020 berdasarkan pada output SPSS tersebut, diperoleh persamaan regresi yaitu $Y=13,582+0,449 X_{1}+0,238 X_{2}$, dimana kefisien regresi bernilai positif.

$\mathrm{H} 1$ = Kepemimpinan transformasional(X1) memiliki pengaruh terhadap semangat kerja pegawai(Y).

Output statistik uji $\mathrm{t}$ pada variabel kepemimpinan transformasional(X1) diperoleh nilai $t_{\text {hitung }}=5,693$ dan singnifikansi $\quad 0,000<0,05, \quad$ sehingga hipotesis 1 (H1) “diterima”.

$\mathrm{H} 2=$ Komitmen organisasi(X2) berpengaruh terhadap semanga kerja pegawai(Y).

Hasil uji statistik uji t pada variabel kepemimpinan transformasional diperoleh nilai $t_{\text {hitung }}=2,816$ dan singnifikansi $0,007<0,05$, sehingga hipotesis $2(\mathrm{H} 2)$ "diterima".

Analisa Uji Simultan (F)

\begin{tabular}{|c|c|c|c|c|c|c|}
\hline \multicolumn{7}{|c|}{ ANOVA $^{\mathrm{b}}$} \\
\hline \multicolumn{2}{|c|}{ Model } & $\begin{array}{l}\text { Sum of } \\
\text { Squares }\end{array}$ & df & $\begin{array}{l}\text { Mean } \\
\text { Square }\end{array}$ & $\mathrm{F}$ & Sig. \\
\hline 1 & $\begin{array}{l}\text { Regressio } \\
n\end{array}$ & 68.058 & 2 & 34.029 & 36.229 & $.000^{\circ}$ \\
\hline 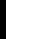 & Residual & 43.207 & 46 & .939 & & \\
\hline 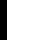 & Total & 111.265 & 48 & & & \\
\hline
\end{tabular}

Sumber: Data Diolah, 2020

$\mathrm{H} 3$ = kepemimpinan transformsional $(\mathrm{X} 1)$ dan Komitmen organisasi(X2) berpengaruh terhadap semangat kerja pegawai(Y).

Hasil statistik uji F secara simultan diperoleh nilai $F_{\text {hitung }}=36,229$ dan singnifikansi $\quad 0,000<0,05, \quad$ sehingga hipotesis 3 (H3) "diterima".

Koefisien Determinasi

\begin{tabular}{|l|l|r|r|r|}
\hline $\begin{array}{l}\text { Mode } \\
\text { I }\end{array}$ & R & R Square & $\begin{array}{c}\text { Adjusted R } \\
\text { Square }\end{array}$ & $\begin{array}{c}\text { Std. Error of } \\
\text { the Estimate }\end{array}$ \\
\hline 1 & $.782^{\text {a }}$ & .612 & .595 & .969 \\
\hline
\end{tabular}




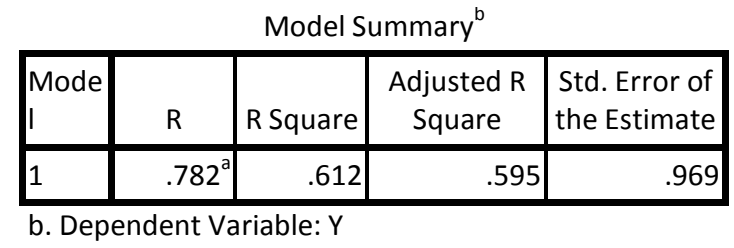

Sumber: Data diolah, 2020

Output Model Summmary diatas diperoleh nilai $R$ Square sebesar 0,612. Hal ini menjelaskan bahwa sebesar $61,2 \%$ merupakan besarnya pengaruh Kepemimpinan transformasional dan Komitmen organisasi terhadap semangat kerja pegawai pada Dinas Tenaga Kerja dan Transmigrasi Kabupaten Bima dan sisanya $38,8 \%$ adalah faktor lain yaitu lingkungan kerja, iklim kerja, kinerja serta lainnya bukan merupakan variabel pada penelitian ini.

Hasil penelitian ini juga membuktikan bahwa kepemimpinan tranformasional dan komitmen organisasi sebagai variabel bebas dalam penelitian ini memiliki kontribusi tinggi $(0,782)$ terhadap variabel terikat yaitu semangat kerja pegawai pada Dinas Tenaga Kerja dan Transmigrasi Kabupaten Bima.

\section{KESIMPULAN DAN SARAN}

Sesuai dengan analisis data serta uji hipotesis diatas dapat disimpulkan bahwa kepemimpinan transformasional mempunyai pengaruh terhadap semangat kerja pegawai; komitmen organisasi memiliki pengaruh terhadap semangat kerja pegawai; serta kepemimpinan transformasional dan komitmen organisasi secara simultan berpengaruh terhadap terhadap semangat kerja pegawai pada Dinas Tenaga Kerja dan Transmigrasi Kabupaten Bima.

Hasil dalam penelitian ini menunjukkan bahwa kepemimpinan transformasional (X1) oleh pimpinan dan komitmen organisasi (X2) yang dimiliki oleh para pegawai dapat meningkatkan serta mengoptimalkan semangat kerja agar tercapainya apa yang menjadi tujuan dari organisasi.

Implikasi yang diharapkan adalah diharapkan dapat menjadi bahan evaluasi dan pertimbangan manejerial demi peningkatan semanagat kerja pegawai.

Melihat masih ada faktor lain selain kepemimpinan transformasional dan komitmen organisasi yang mempengaruhi semangat kerja pegawai, maka kiranya perlu penelitian lebih lanjut terhadap dimensi-dimensi yang diduga mampu memberikan efek pengaruh pada semangat kerja pegawai pada Dinas Tenaga Kerja dan Transmigrasi Kabupaten Bima.

\section{DAFTAR PUSTAKA}

Danim, Sudarwan.2004. Motivasi dan kepemimpinan dan efektivitas kelompok. PT Remaja Rosdakarya. Bandung.

Fane, Sugeng Mianto. 2016. Pengaruh Komitmen Organisasi dan Motivasi Kerja Terhadap Semangat Kerja Karyawan CV. Tunas Pratama Palembang. Jurnal Manajemen. Vol. 4 No.3 Juli 2016. ISSN:2089-6832.

Galih dan Azis, 2017. Analisis Pengaruh Gaya Kepemimpinan Dan Motivasi Kerja Terhadap Kinerja Pegawai Pada Dinas Tenaga Kerja Provinsi Lampung, Staff Pengajar Jurusan Administrasi Negara. Universitas Bandar Lampung.

Hasibuan, Malayu. 2013. Manajemen Sumber Daya Manusia. Jakarta: PT bumi Aksara

Hartono, Jogiyanto. 2009. Sistem Teknologi informasi. Yogyakarta

Hermawan, Asep. 2009. Penelitian Bisnis. Jakarta: PT Grasindo

Mardani.2013. Pengaruh Kepemimpinan, Moivasi, Kepuasan Kerja 
Jurnal Ilmiah Ekonomi dan Bisnis

Vol. 17. No.1, Maret 2020 : 79-84

EISSN : $2442-9813$

Terhadap Komitmen

Organisasional Dan Kinerja

Karyawan Pada Karyawan PT.

Smartfren, Tbk Di Surabaya.

Universitas Airlangga

Mangkunegara, Anwar. 2008. Manajemen

Sumber Daya manusia. Remaja

Rosdakarya, Bandung.

Sugiyono.2009. Metode penelitian

kuantitatif fan kualitatif.

Bandung : Alfabeta.

Suharsimi, Arikunto (2010). Prosedur Penelitian Suatu Pendekatan Dan Praktik. Jakarta: rinek cipta.

Suparyadi. 2015. Manajemen Sumber Daya Manusia, Menciptakan Keunggulan Bersaing Berbasis Kompetisi SDM. Jakarta: Andi.

Yulk, Gary.2010. Kepemimpinan dalam Organisasi, Edisi Kelima. Jakarta: PT. Indeks. 